\title{
Studies of amino acid requirements of adult rats*
}

\author{
By ELIZABETH B. SMITH† AND B. C. JOHNSON† \\ Division of Nutritional Biochemistry, Department of Animal Science, \\ University of Illinois, Urbana, Illinois, USA
}

(Received I April 1966-Accepted 30 September 1966)

\begin{abstract}
I. A series of experiments was carried out to determine the minimum essential amino acid requirements of the adult rat.

2. After testing four amino acid patterns taken from the literature, a basal pattern was formulated in which each amino acid appeared at the lowest level at which it was presented in any of the original diets.

3. Nitrogen balance was the main criterion used to judge any benefit arising from modest increases in individual amino acids tested in a modified Latin-square design. They were given at a protein level of $3.6 \%$ of the diet. Non-essential amino acids were in the same proportions as in whole egg.

4. It appeared that three amino acids, namely tryptophan, threonine and isoleucine, brought about more favourable balances when presented at concentrations higher than basal.

5. Reduced levels of each amino acid were then tested in order to ensure that no surpluses were present.

6. $\mathrm{N}$ retentions indicated that lysine, phenylalanine plus tyrosine, leucine and valine could be reduced below the basal level and still meet the needs of the rat for these amino acids.

7. When the pattern of amino acids arising from these latter trials was tested in combination, rather than as trios, pairs, or single changes, positive $\mathrm{N}$ balances gave confidence that these were minimal levels of the essential amino acids required for meeting the maintenance needs of adult rats.

8. Plasma proteins from the rats on the evolved pattern were found to be in no way different from those found for normal animals. This gave further support to the belief that the pattern was adequate for the rats.
\end{abstract}

The object of these studies was to determine the minimum essential amino acid requirements of adult rats as a first step towards the development of a pattern of human amino acid requirements. A survey of the literature on amino acid requirements of adult rats shows poor agreement among published values (Nasset, 1956; Benditt, Woolridge, Steffee \& Frazier, I950; Mitchell \& Beadles, 1950). The series of investigations to be reported here was carried out in three phases. Each phase represented the time period during which a single set of animals was studied. Each period within a phase represented a test involving a particular treatment. The aim of phase $I$, carried out in one period only, was to establish which of several patterns of amino acid requirement might best serve as a basal or control pattern for the starting point of the study. The pattern evolved from this was then used in phase 2 to test the possibility that modest increases of individual amino acids might improve the basal pattern. Three periods were required to test these increments. Phase 3 consisted of six periods to measure the consequence of various decrements in the amino acid reference pattern which arose from phase 2 .

* Portion of a thesis presented by E. B. Smith as partial fulfilment of the requirements for the degree of $\mathrm{PhD}$.

$\uparrow$ Present adress : School of Home Economics, University of Manitoba, Winnipeg 19, Manitoba, Canada.

† Present address: Medical Center, University of Oklahoma, Oklahoma City, Oklahoma, USA. 


\section{EXPERIMENTAL}

\section{Phase I}

Animals. Forty male Wistar rats aged $5^{-6}$ months and weighing from 200 to $25^{\circ} \mathrm{g}$ were randomly assigned to cages which had raised wire bottoms as a deterrent to coprophagy.

\begin{tabular}{|c|c|c|c|c|}
\hline Amino acid & $\begin{array}{c}\text { Diet no. If } \\
\text { (whole egg**) }\end{array}$ & $\begin{array}{l}\text { Diet no. } 2 \S \\
\text { (adult rats) }\end{array}$ & $\begin{array}{l}\text { Diet no. } 3 \| \\
\text { (adult rats) }\end{array}$ & $\begin{array}{c}\text { Diet no. } 4 \\
\text { (growing rats) }\end{array}$ \\
\hline L-lysine hydrochloride & 0.268 & 0.046 & 0.156 & 0.360 \\
\hline L-histidine hydrochloride & 0.107 & 0.086 & 0.088 & 0.092 \\
\hline L-phenylalanine & 0.320 & 0.185 & 0.104 & 0.224 \\
\hline I-tryptophan & $0.06 \mathrm{I}$ & 0.045 & $0.06 \mathrm{I}$ & 0.048 \\
\hline L-methionine & 0.179 & 0.411 & 0.179 & 0.259 \\
\hline L-threonine & 0.179 & 0.205 & 0.171 & $0 \cdot 160$ \\
\hline L-leucine & 0.272 & 0.164 & 0.218 & 0.224 \\
\hline $\mathrm{L}$-isoleucine & 0.227 & 0.308 & 0.433 & 0.176 \\
\hline I-valine & 0.266 & 0.185 & 0.236 & 0.176 \\
\hline 'Total & $\mathrm{r} \cdot 879$ & $I \cdot 635$ & $I \cdot 646$ & $1 \cdot 719$ \\
\hline
\end{tabular}

* The initial purified diets contained $12 \%$ fat contributed by $5 \%$ each of lard and maize oil, I.5\% cod-liver oil and $0.5 \%$ wheat-germ oil, $4 \%$ salt mixture no. 446 (Mameesh \& Johnson, 1959 ), I \% $\mathrm{NaCl}$, $2 \%$ cellulose, $10 \%$ sucrose, $5 \%$ vitamin mixture in dextrinized starch, $2.75-4 \%$ protein from either dried whole egg or free amino acids, and dextrinized maize to roo parts. Later the fat content was increased to $18 \%$ at the expense of dextrin. The vitamin mixture was (g): choline chloride $20 \% 0$, thiamine hydrochloride 0.5 , riboflavine 0.32 , calcium $D$-pantothenate $0 \cdot 8$, nicotinic acid $2 \cdot 0$, pyridoxine $0 \cdot 12$, biotin 0.012 , folic acid 0.08 , menaph thone $0.02, p$-aminobenzoic acid $2 \cdot 0$, inositol 4.0 , cyanocobalamin $(0.1 \%$ in mannitol) $\mathrm{I} \cdot 15$, dextrinized starch $969 \circ 0$.

+ All diets contained a mixture of $50 \%$ maize starch $+50 \%$ non-essential amino acids : L-arginine 4.9 , DL-alanine 6, L-aspartic acid. I0.8, L-glutamic acid $12 \cdot 6$, L-proline $4 \cdot 5$, DL-serine $7 \cdot 2$, glycine 4 , and dextrinized maize 5o. Essential amino acids varied according to design; the supplement of non-essential amino acids brought the protein content of each diet up to $3.2 \%$.

$\ddagger$ See Harvey (1956).

$\S$ See Nasset (1956).

$\|$ See Benditt et al. (1950).

See Rama Rao et al. (I959).

** Dried defatted egg was prepared by the Animal Nutrition Division of the University of Illinois. By analysis it was found to contain I $13 \mathrm{mg} \mathrm{N} / \mathrm{g}$.

Diet and design. After a 2-week stabilizing period during which a purified diet containing $4 \%$ protein from dried whole egg was given, each group of ten animals received for 2 weeks one of four amino acids diets as shown in Table $\mathrm{I}$. The essential amino acid compositions of these diets were based on: (I) whole egg, according to Harvey (1956); (2) amino acid requirements of the adult rat, according to Nasset (1956); (3) amino acid requirements of the adult rat, according to Benditt et al. (1950); (4) amino acid requirements of the growing rat as recommended by Rama Rao, Metta $\&$ Johnson (1959).

The $3.2 \%$ protein level used was that found by Hartsook \& Mitchell (1956) to maintain nitrogen equilibrium in the adult rat receiving whole egg protein. The nonessential amino acid mixture (Table I) was modelled on that of whole egg, but lacked cystine and tyrosine, since allowance had been made for these in the amounts of 
methionine and phenylalanine used in the whole-egg pattern. The mixture was added to the diets in the amounts needed to bring the total $\mathrm{N}$ to $0.512 \%$ of the diet.

The amount of complete diet required to maintain body-weight was determined for each animal during a preliminary feeding period. Usually this predetermined amount, offered daily, required little subsequent adjustment.

Analytical methods. Excreta were collected during the last 4 days of a 2-week test period. $\mathrm{N}$ determinations on all the diets and excreta were made at first on a macroKjeldahl unit by the method of the Association of Official Agricultural Chemists (1955). After receipt of a micro-apparatus, the method of Clark (194I) with modifications suggested by Hiller, Plazin \& Van Slyke (1948) was used for analyses of diet and urine. Diets were routinely analysed before being given to the animals. Faecal samples were digested in toto after the hair had been carefully removed by the method of V. C. Metta ( 1959 , private communication), and a portion was used for the determination of $\mathrm{N}$.

\section{Phase 2 (periods I, 2, 3)}

Animals. Twenty-four male Wistar rats, 8-9 months old were selected at random and assigned to individual cages in an air-conditioned room.

Diet and design. To determine the minimum protein requirement of these rats a diet in which the $\mathrm{N}$ was supplied by dried whole egg was given during period $\mathrm{r}$. The amount was varied to provide from $2 \cdot 65$ to $3 \cdot 88 \%$ dietary protein (by analysis).

In the following periods of phase 2 only, $I \cdot 5 \%$ whole egg protein was included in the diets to improve palatability, and all the amino acids were added as increments to the levels present in the egg protein, their basal pattern being derived from the results of phase $\mathrm{I}$. Because the amount of lysine contained in $\mathrm{x} \cdot 5 \%$ egg protein was greater than the basal level plus the lowest increment, no lysine supplement was added.

All increments were tested in trios, and in three different combinations according to a modified Latin-square design, as shown in Table 2. The amounts of methionine and cystine were not altered, but kept at $8.05 \%$ of the protein, requirements for them having been thoroughly studied by Hartsook \& Mitchell (r956). Such a design allows the maximum information to be obtained from one test. For example, Table 2 shows that, whereas diets $1-4$ gave nine expressions of the influence of three amino acids at altered levels, the same number of diets involving single testing could contribute only three $\mathrm{N}$ retention values.

Table 2 shows the amino acid content of the two basal diets (nos. I and I2) and that of the ten test diets for period 2. It was necessary to test five of the diets (as well as a basal one) at a time in order to provide four animals per pattern tested. Also shown in Table 2 are the compositions of diets nos. $13, I_{4}$ and 15 for period 3 during which further changes were tested in pairs, with diet no. 16 serving as the control diet. The level of phenylalanine plus tyrosine of $0.14 \%$ provided by the $1.5 \%$ egg protein of the basal diet was above the minimal level of $0.10 \%$ used in phase 1 . The basal level used in these experiments was $0.175 \%$. Cystine and tyrosine were incorporated with the essential amino acids so that their levels could be controlled precisely. The ratios of cystine and tyrosine to methionine and phenylalanine respectively were as in whole egg (Harvey, I956). The non-essential amino acid mixture was that used in phase I. 


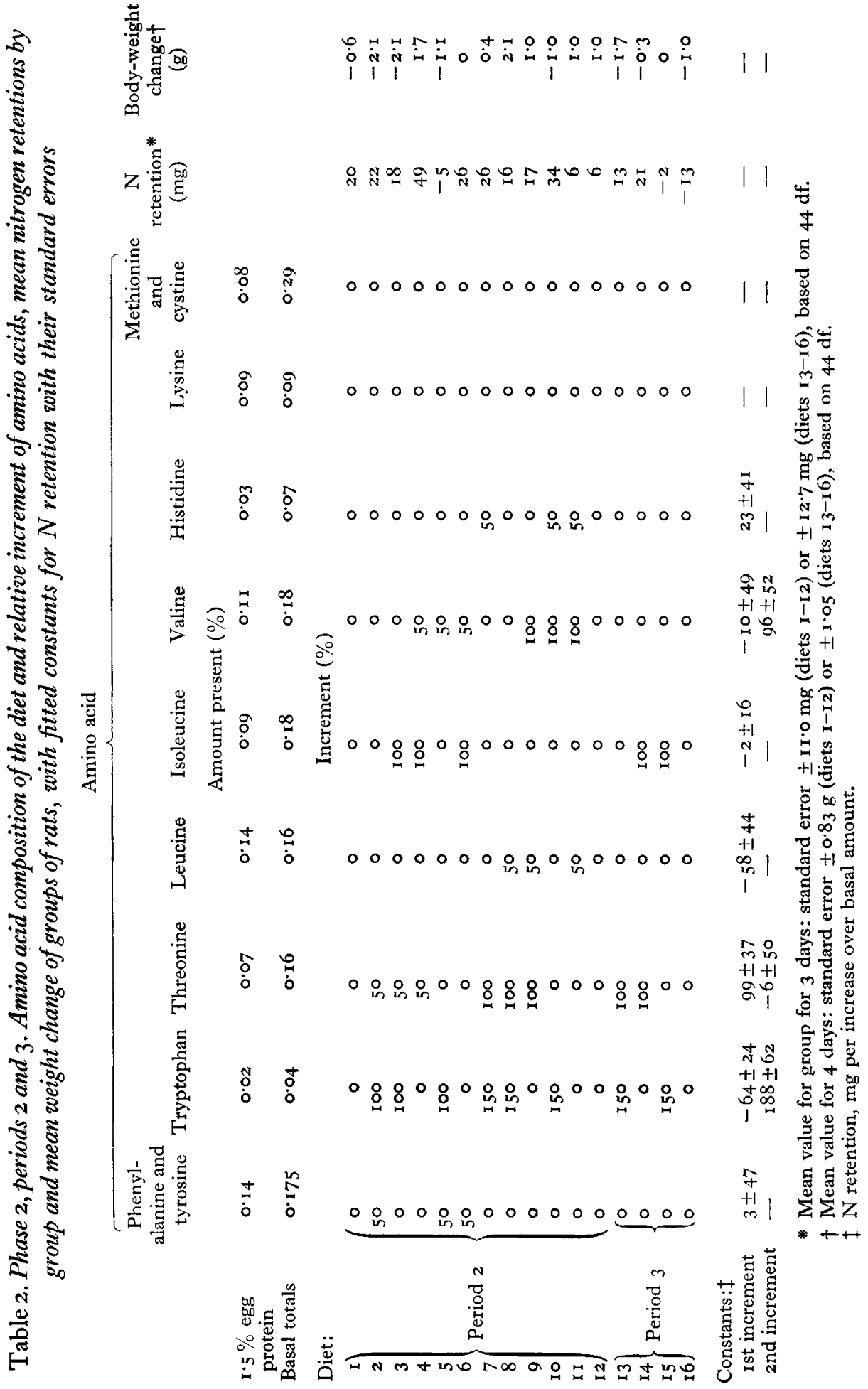


Table 3. Phase 3. Effect of reduced levels of individual amino acids in the diet of rats on nitrogen retention and body-weight in a 4-day period

\begin{tabular}{|c|c|c|c|c|}
\hline Period & Amino acid varied & $\begin{array}{l}\text { Amount in } \\
\text { diet* }(\%)\end{array}$ & $\begin{array}{l}\mathrm{N} \text { retentiont } \\
(\mathrm{mg})\end{array}$ & $\begin{array}{c}\text { Weight } \\
\text { changet }(\mathrm{g})\end{array}$ \\
\hline \multirow[t]{8}{*}{$\mathbf{I}$} & Lysine & 0.025 & 23 & -8 \\
\hline & & 0.05 & I7 & -4 \\
\hline & & 0.075 & -4 & -4 \\
\hline & & 0.09 & $\mathbf{r}_{3}$ & -4 \\
\hline & Histidine & 0.035 & $-r_{4} \downarrow$ & $-5 t$ \\
\hline & & 0.05 & -13 & 0 \\
\hline & & 0.07 & 4 & 2 \\
\hline & & 0.105 & -47 & -3 \\
\hline \multirow[t]{8}{*}{2} & Phenylalanine + tyrosine & 0.088 & -22 & -2 \\
\hline & & 0.131 & -37 & I \\
\hline & & $0 \cdot 175$ & -96 & $\mathrm{r}$ \\
\hline & & 0.262 & 2 I & $\mathbf{I}$ \\
\hline & Tryptophan & 0.04 & -40 & $\mathbf{I}$ \\
\hline & & 0.05 & -36 & 7 \\
\hline & & 0.06 & -34 & -2 \\
\hline & & 0.08 & -90 & -3 \\
\hline \multirow[t]{8}{*}{3} & Threonine & 0.12 & $-\mathbf{I 3 2}$ & -9 \\
\hline & & 0.16 & $-8 I$ & -8 \\
\hline & & 0.20 & -56 & -2 \\
\hline & & 0.24 & -68 & -3 \\
\hline & Leucine & 0.10 & -9 & -4 \\
\hline & & 0.12 & -40 & -3 \\
\hline & & $0 \cdot 16$ & 22 & 0 \\
\hline & & 0.20 & I3 & 0 \\
\hline \multirow[t]{6}{*}{4} & Isoleucine§ & $\longrightarrow$ & 一 & - \\
\hline & & 0.18 & $25 t$ & If \\
\hline & & $\begin{array}{l}0.24 \\
0.36\end{array}$ & $\begin{array}{l}51 \\
38+\end{array}$ & $\begin{array}{l}\text { I } \\
\text { of }\end{array}$ \\
\hline & Valine & 0.12 & 42 & $-\mathbf{I}$ \\
\hline & & $\begin{array}{l}0.15 \\
0.18\end{array}$ & $\begin{array}{l}41 \\
45 t\end{array}$ & $\begin{array}{l}\text { o } \\
\text { of }\end{array}$ \\
\hline & & 0.21 & 4 & -1 \\
\hline \multirow[t]{8}{*}{5} & Lysine & 0.05 & 4 & $\circ$ \\
\hline & Phenylalanine + tyrosine & 0.13 & $3 I$ & 3 \\
\hline & Tryptophan & 0.04 & 48 & $-\mathbf{I}$ \\
\hline & Threonine & 0.16 & $24 t$ & of \\
\hline & Leucine & 0.10 & Io & -2 \\
\hline & Isoleucine & 0.24 & $45 t$ & of \\
\hline & Valine & 0.12 & 4 & 0 \\
\hline & Basal & - & 23 & $\mathbf{I}$ \\
\hline
\end{tabular}

* The amino acid values in bold-faced type indicate the composition of the 'basal' diet evolved from phase 2 tests.

$t$ The standard errors of average $\mathbf{N}$ retention and average weight change, based on 73 degrees of freedom, were \pm 20 and $\pm 2 \cdot 3$ respectively, for three rats, \pm 24 and $\pm 2 \cdot 9$ for two rats, for the comparisons involving changes in a single amino acid, and generally in period 5 . The corresponding values for comparisons within columns would be less because the same rats are involved except where substitutions were necessary.

$\mp$ Only two rats per group.

$\S$ The fat content of the diet was increased from i2 to $18 \%$ after period 3 . 
That amount required to bring the $\mathrm{N}$ of the essential amino acids to a total of $0.57^{6} \mathrm{~g}$ $\mathrm{N} / \mathrm{roo} \mathrm{g}$ diet was added to each diet.

During period 3, amino acids which had appeared to produce the most equivocal responses in period 2 were re-tested in pairs in two different combinations (Table 2). All the test diets were given for I week, excreta being collected during the last 3 days. The experimental period was preceded by an equilibrating period on a $4 \%$ eggprotein diet. This period lasted for not less than 3 days or until the analyses of the samples from the previous period could be completed.

Analytical methods. Samples of blood were taken by cardiac puncture on the final day of each period of phases 2 and 3 . Plasma proteins were separated by paper electrophoresis according to the method of Jencks, Jetton \& Durrum (1955), in order to provide some other evidence of protein adequacy besides that of $\mathrm{N}$ balance. $\mathrm{N}$ determinations were made as before.

Table 4. Phase 3, period 6 . Nitrogen balances of the rats for 4 days

\begin{tabular}{|c|c|c|c|c|c|c|}
\hline Rat no. & $\begin{array}{c}N \text { intake } \\
(\mathrm{mg})\end{array}$ & $\underset{(\mathrm{mg})}{\text { Urinary } N}$ & $\begin{array}{l}\text { Faecal N } \\
\quad(\mathrm{mg})\end{array}$ & $\begin{array}{l}\text { N output } \\
(\mathrm{mg})\end{array}$ & $\begin{array}{l}\text { N balance } \\
(\mathrm{mg})\end{array}$ & $\begin{array}{l}\text { Change in } \\
\text { body-weight } \\
\text { (g) }\end{array}$ \\
\hline \multicolumn{7}{|c|}{ Test diet* } \\
\hline $\mathrm{r}$ & 346 & 199 & 95 & 294 & 52 & I \\
\hline 2 & 369 & 283 & 102 & 385 & $-I 6$ & 0 \\
\hline 3 & 346 & 204 & 82 & 286 & 60 & 5 \\
\hline 5 & 357 & 220 & 95 & 315 & 42 & I \\
\hline 6 & 369 & 225 & 100 & 325 & 44 & $-I$ \\
\hline 7 & 369 & $24 \mathrm{I}$ & 105 & 346 & 23 & -3 \\
\hline 9 & 369 & 220 & 94 & 304 & 55 & $-I$ \\
\hline II & 369 & 217 & 95 & 312 & 57 & 2 \\
\hline 12 & 317 & 225 & 82 & 307 & IO & -4 \\
\hline \multicolumn{5}{|c|}{ Mean value with its standard error } & $3^{6} \pm 8$ & $0 \pm 0.9$ \\
\hline \multicolumn{7}{|c|}{ Basal diet* } \\
\hline I4 & 369 & 210 & 92 & 302 & 67 & 5 \\
\hline 15 & 369 & 196 & 112 & 308 & 6I & 2 \\
\hline 16 & 369 & 217 & 98 & 315 & 54 & 2 \\
\hline I8 & 369 & 175 & 112 & 287 & 82 & 3 \\
\hline 19 & 369 & 217 & 117 & 334 & 35 & 3 \\
\hline 20 & 369 & I93 & 123 & 316 & 53 & 3 \\
\hline $2 \mathrm{I}$ & 363 & 220 & 114 & 334 & 29 & 5 \\
\hline 22 & 363 & 223 & 95 & 318 & 45 & 4 \\
\hline 23 & 369 & 217 & 96 & 313 & 56 & 7 \\
\hline 24 & $3^{69}$ & 225 & 128 & 353 & 16 & 5 \\
\hline \multicolumn{5}{|c|}{ Mean value with its standard error } & $50 \pm 7$ & $4 \pm 0.8$ \\
\hline
\end{tabular}

* The amino acid compositions of the diets $(\mathrm{g} / \mathrm{roo} \mathrm{g})$ were:

\begin{tabular}{lccccccccc} 
& \multicolumn{7}{c}{ Phe+ } & \multicolumn{7}{c}{ Met+ } \\
Test diet & Lys & His & tyr & Try & cys & Thr & Leu & Ile & Val \\
Basal diet & 0.05 & 0.07 & 0.13 & 0.04 & 0.29 & 0.16 & 0.10 & 0.24 & 0.15 \\
& 0.09 & 0.175 & 0.08 & 0.29 & 0.24 & 0.16 & 0.36 & 0.18
\end{tabular}

Phase 3 (six periods)

Animals. Twenty-four mature male Wistar rats aged about 8 months and weighing on average $390 \mathrm{~g}$ (range $35^{\circ}-425 \mathrm{~g}$ ) were selected at random and assigned to wire cages which had raised wire bottoms. 
Design and diets. Eight essential amino acids were investigated by testing each of them singly in four experimental periods (Table 3 ). For the most part these levels were decrements of the basal pattern evolving from phase $\mathrm{I}$. However, because of equivocal results for certain of the amino acids (threonine, isoleucine and tryptophan) at the increased levels tested in phase 2 and in order to provide a cross-check of single testing versus three variables, a slight increase of most of the amino acids was tested along with the decreases. During a fifth period indicated reductions of single amino acids were retested. Period 6 incorporated all indicated changes into one test diet and $\mathrm{N}$ balances on this diet were compared with $\mathrm{N}$ balances on the basal or reference diet that arose as a result of phase 2 tests. For convenience the amino acid levels tested are shown in Table 4. Eleven animals were used for each diet. As before, the sulphurcontaining amino acid levels were those established by Hartsook \& Mitchell (1956).

All the diets, including the egg-protein diet, were similar in composition to those in phase 2 with respect to the non-nitrogenous constituents, the one exception being the fat content. As will be noted, rather consistently negative $N$ balances led us to increase the caloric density after period 3. This accomplished the desired result in period 4. Hence the higher fat content of $18 \%$ (from lard and maize oil added at the expense of dextrin) was retained also in periods 5 and 6 . The $4 \%$ egg-protein equilibration diet was likewise thereafter mixed to contain $18 \%$ fat.

\section{RESULTS AND DISCUSSION}

\section{Phase I}

Some of the diets were poorly accepted by the animals, perhaps because of the high levels of phenylalanine, since this amino acid was supplied in an amount equal to the level of phenylalanine plus tyrosine in the various patterns tested. The diet patterned on whole egg, containing $0.32 \%$ phenylalanine (the highest concentration used), was refused to a considerable extent by nine of ten rats. For the other three patterns mean body-weight changes for the ten rats/group ranged from a loss of $\mathrm{I} \cdot 8 \mathrm{~g}$ to a gain of $2 \mathrm{~g}$ during the 2 weeks on test.

Since on the basis of weight maintenance and general physical appearance there was no reason to believe that any of the patterns tested in phase I were deficient in any amino acid, the lowest level of each essential amino acid given in phase $\mathbf{I}$ was used to formulate the basal pattern for phase 2 (see Table 2 ).

\section{Phase 2}

When the resulting $\mathrm{N}$ balances of the rats in period I were plotted against $\mathrm{N}$ intake, the zone of equilibrium for these animals was placed at $3.6 \%$ protein in the diet (results not shown).

Constants fitted to the values for periods 2 and 3 by the method of least squares and shown in Table 2 indicate that the basal diet was adequate in the amino acids tested, except for threonine and possibly tryptophan. For threonine the second increment did not increase $\mathrm{N}$ retention, so that a $50 \%$ increase over the amount present in the basal diet, to a total of $0.24 \%$, was probably adequate. For tryptophan the results were 
contradictory, the $100 \%$ increment having led to a decrease and the $150 \%$ increment to an increase, both statistically significant at the 2 and $\mathrm{r} \%$ levels respectively. This discrepancy in the values of the constants for the two increments and their high standard errors in all five tests involving the $150 \%$ increase made it necessary to consider further testing of tryptophan.

Since isoleucine was a member of the triad which gave the best retention in period 2 , these three amino acids, namely threonine, tryptophan and isoleucine, were chosen for retesting in period 3 in pairs. This test seemed to indicate that threonine, at $100 \%$ increase over the basal level, conferred no benefit greater than did the $50 \%$ increase of period 2.

\section{Phase 3}

Because it was so difficult to interpret the results for tryptophan when increased by $100 \%$, and in order to obtain additional evidence for the effect of increasing threonine by $50 \%$, tryptophan and threonine at increases of $100 \%$ and $50 \%$ respectively and isoleucine increased by $100 \%$ were incorporated in the new basal or reference pattern of phase 3 . All the basal levels are shown as bold figures in Table 3 .

Mean values for the $\mathrm{N}$ retentions of groups of rats indicated that lysine might be reduced even to $0.025 \%$. For histidine $0.07 \%$ seemed adequate, but it was dubious whether a lesser amount would be. Variations in phenylalanine plus tyrosine gave $\mathrm{N}$ retentions which were statistically significantly $(P<0.001)$ heterogeneous and showed no clear trend. However, a level of $0.131 \%$ appeared to be safe. The results for tryptophan suggested that the amount of that amino acid might be reduced to $0.04 \%$, which was not unexpected in view of the previous trial. Reductions of threonine to $0.16 \%$ seemed likely to be safe, and leucine could probably be kept at $0.10 \%$. Among the three levels of isoleucine tested, $0.24 \%$ seemed better than $0.18 \%$. Valine apparently might be reduced to $0.12 \%$. Thus, of the three amino acids which were adjusted upwards for the reference levels for phase 3, only one, namely isoleucine, appeared to serve better in meeting the rats' needs at a level higher than that of the phase 2 basal diet.

The increased caloric density should be credited for the conspicuous change to positive $\mathrm{N}$ retentions in periods 4 and 5 . A direct comparison of the two energy levels came about inadvertently in period 4 . Instead of a low level of isoleucine (0.12\%) a low level of threonine was introduced in error. Results showed that the same level of threonine at the higher fat concentration brought about a positive balance.

When the indicated levels were tested further in period 5, except that valine was reduced to $0.12 \%$ and lysine to only $0.05 \%$, most of the animals reacted favourably, only five of twenty-two showing negative retentions, and the group mean retention was always positive.

The observed $\mathrm{N}$ retentions gave no substantial indication that any amino acid level tested was too low. The lowest retentions were observed for lowered lysine and lowered valine, but the lysine test in period I gave confidence that $0.05 \%$ was not too low. It was doubtful whether $0.12 \%$ valine was adequate, and $0.15 \%$ was tested in period 6 (Table 4). The reduced levels of $0.16 \%$ for threonine and $0.10 \%$ for leucine appeared to be satisfactory for these animals. 
Two rats, one from each group, appeared unthrifty toward the end of the final test period of phase 3 . Results for them were not included in calculating the mean $\mathrm{N}$ balance values given in Table 4. Also, results for one rat on the test diet were lost when a flask broke. Of the nine remaining rats on the test diet, only one was in negative $\mathrm{N}$ balance; all ten rats consuming the control diet were in positive balance. Mean $\mathrm{N}$ retentions by the group for 4 days were $36 \pm 7.5$ and $50 \pm 7 \cdot \mathrm{r}$ mg for test and basal diets. The hypothesis that the test diet might give lower retentions only was rejected on the basis that the difference in mean $\mathrm{N}$ retentions did not reach even the 10\% significance level.

Body-weights (not shown) remained relatively constant during the 2 weeks on this diet, but the test animals gained significantly less $(P<0.01)$ than the controls.

Separation of the plasma proteins sampled in phases 2 and 3 and analysis of the results showed the concentrations of the various fractions to be in no way altered from those of normal adult animals chosen from the colony.

Essential amino acid requirements indicated by these trials are given (Table 5 ) as a percentage of diet, as $\mathrm{mg} / \mathrm{kcal}$, and as $\mathrm{mg} /$ day with a food intake of $16 \mathrm{~g}$ daily.

\section{Table 5. Revised tentative list of minimum requirements of essential amino acids for maintenance of the adult rat}

\begin{tabular}{lccc} 
& \multicolumn{3}{c}{ Requirement expressed as: } \\
\cline { 2 - 4 } Amino acid & $\%$ of diet & mg/kcal & $\mathrm{mg} / \mathrm{day}$ \\
Lysine & 0.05 & $0.1 \mathrm{I}$ & 8.0 \\
Histidine & 0.07 & 0.15 & $\mathrm{II} \cdot 2$ \\
Phenylalanine & 0.075 & 0.17 & $12 \cdot \mathrm{I}$ \\
Tyrosine & 0.056 & 0.13 & $9 \cdot 6$ \\
Tryptophan & 0.04 & 0.09 & 6.4 \\
Methionine & 0.166 & 0.36 & $26 \cdot 4$ \\
Cystine & 0.124 & 0.27 & 19.8 \\
Threonine & 0.16 & 0.35 & 25.5 \\
Leucine & 0.10 & 0.22 & 16.0 \\
Isoleucine & 0.24 & 0.52 & 38.2 \\
Valine & 0.15 & 0.33 & 24.0
\end{tabular}

The energy aspects of this study deserve comment, for it appeared that a rather slight rise in the ratio of non-protein to protein calories was the sole factor responsible for a definite swing from a predominantly negative to an almost consistently positive $\mathrm{N}$ balance.

The animals were receiving a liberal supply of total energy according to Nasset's (1956) principle that an adult rat can maintain its body-weight within $\pm 3 \%$ for several months when receiving a daily calorie allowance in kcal equal to I2I $W^{0 \cdot 75}$ (where $W$ is the weight in $\mathrm{kg}$ ), so that a $380 \mathrm{~g}$ rat would need $59 \mathrm{kcal}$. The actual daily intake of $67 \mathrm{kcal}$ before, and $72 \mathrm{kcal}$ after the increase in fat level was therefore judged ample at all times.

The faeces and urine, analysed before and after the calorie increase, contained essentially the same amount of faecal $\mathrm{N}$, but the high-fat diet appeared to have a $\mathrm{N}$-sparing effect on the endogenous urinary $\mathrm{N}$. This observation agrees with the report 
by Mitchell (1934) that the substitution of fat for starch does not affect the excretion of metabolic faecal $\mathrm{N}$.

In view of the small increase in total energy intake, one is led to consider possible factors other than a direct $\mathrm{N}$-sparing effect of fat which might have exerted an influence. Several workers, including Annegers \& Ivy (1947), McSwiney \& Spurrell (1935) and Schreiber \& Elvehjem (1955), have attributed the better utilization of dietary protein, when the fat moiety was increased, to the delay in gastric evacuation. Studies of Rogers, Chen, Peraino \& Harper ( 1960 ) have demonstrated that a free amino acid mixture leaves the stomach and is absorbed from the small intestine more rapidly than equivalent amounts of whole protein. It seems possible that the increment of $6 \%$ fat conferred a delaying action sufficient to re-establish the sequence of events in energy metabolism so that amino acids are released according to a schedule which more closely resembles that which obtains in protein metabolism.

Another possibility to be entertained is that the reduced ratio of essential to nonessential amino acids may have induced a greater sensitivity on the part of the animals to altered ratios within the essential amino acids than obtained before reductions were tested. As may be seen from Table 4, the total amounts of essential amino acids supplied in phase 3 diets were approximately $35 \%$ lower than they were in many tests of phase 2 .

Table 6. Comparison of amino acid requirements of adult rats: values from three workers expressed as (I) $m g / \mathrm{W}^{0.75}$ day, ${ }^{*}$ and (2) as ratios when tryptophan is taken as $0.04 \%$

(I)

\begin{tabular}{|c|c|c|c|}
\hline Amino acid & $\begin{array}{l}\text { Nasset } \\
\text { (r956) }\end{array}$ & $\begin{array}{l}\text { Benditt et al. } \\
\quad(1950)\end{array}$ & 'This study \\
\hline Lysine & 4 & 35 & Io \\
\hline Histidine & 7 & 20 & 14 \\
\hline Phenylalanine & I 8 & 29 & I6 \\
\hline Tryptophan & $4 \cdot 4$ & I7 & 8 \\
\hline Methionine & 40 & so & 34 \\
\hline Threonine & 20 & 48 & 33 \\
\hline Leucine & 16 & $6 I$ & 20 \\
\hline Isoleucine & 30 & I 2 I & 49 \\
\hline Valine & 18 & 66 & 31 \\
\hline
\end{tabular}

$\begin{array}{lcc}\begin{array}{c}\text { Nasset } \\ \text { (I956) }\end{array} & \begin{array}{c}\text { Benditt etal. } \\ \text { (I950) }\end{array} & \text { This study } \\ 0.03 & 0.08 & 0.05 \\ 0.06 & 0.05 & 0.07 \\ 0.16 \dagger & 0.07 & 0.08 \\ 0.04 & 0.04 & 0.04 \\ 0.36 \dagger & 0.12 & 0.17 \\ 0.18 & 0.11 & 0.16 \\ 0.14 & 0.14 & 0.10 \\ 0.27 & 0.28 & 0.24 \\ 0.16 & 0.15 & 0.15\end{array}$

* $W$, body-weight in $\mathrm{kg}$.

+ If the phenylalanine:tyrosine ratio be adjusted to equal $r: 0 \cdot 75$, the phenylalanine value becomes 0.09 ; similarly, the methionine value becomes $0.2 \mathrm{I}$.

A comparison of the amino acid requirements proposed here as tentative values with those published by others and used as starting points in this study is of interest. Benditt et al. (1950) and Nasset (1956) differ first in the total amounts of essential amino acids they recommend (Table I). Though the work reported here showed that a total essential amino acid content of $\mathrm{r} \cdot 24 \%$ of the $\operatorname{diet}$ (including tyrosine and cystine) is sufficient, they reported values of $\mathrm{I} \cdot 84$ and $\mathrm{I} \cdot 85 \%$ of the diet, respectively, when the total protein was adjusted to $3.6 \%$ of the diet.

Absolute daily requirements expressed in amounts of amino acid per $W^{0.75}$ per day showed little agreement with those of Benditt et al. and of Nasset (see Table 6). How- 
ever, comparisons of the ratios in which the amino acids were present in the three sets of values with tryptophan set at $0.04 \%$ in all revealed a surprising amount of similarity. Moreover, with Nasset's data, when a portion to represent tyrosine was deducted from the phenylalanine figure and likewise when a value for cystine was deducted from that for methionine, the resultant ratios of 0.09 and 0.21 respectively brought the three patterns of amino acids into much closer agreement.

The authors acknowledge the great amount of statistical help in the analyses of the results given by Dr H. W. Norton, Department of Animal Science, University of Illinois. The co-operation of Dr A. J. Wood, Director of the Central Animal Depot, University of British Columbia, Vancouver, British Columbia, in providing space for some of this work is acknowledged. We are also grateful for donations from this source of all the experimental animals used. These studies were supported in part under Contract no. DA-49-007-MD-544, with the Office of the Surgeon General, Department of the US Army.

\section{REFERENCES}

Association of Official Agricultural Chemists (1955). Official Methods of Analysis, 8th ed., p. 12. Washington, D.C.: Association of Official Agricultural Chemists.

Annegers, J. H. \& Ivy, A. C. (1947). Am. F. Physiol. 150, 46r.

Benditt, E. P., Woolridge, R. L., Steffee, C. H. \& Frazier, L. E. (1950). F. Nutr. 40, 335.

Clark, E. P. (1941). F. Ass. off. agric. Chem. 24, 641.

Hartsook, E. W. \& Mitchell, H. H. (1956). F. Nutr. 6o, I73.

Harvey, D. (1956). Tech. Commun. Commonw. Bur. Anim. Nutr. no. 19.

Hiller, A., Plazin, J. \& Van Slyke, D. D. (1948). F. biol. Chem. 176, I401.

Jencks, W. P., Jetton, M. R. \& Durrum, E. L. (I955). Biochem. $\mathscr{f} .60,205$.

McSwiney, B. A. \& Spurrell, W. R. (I935). F. Physiol., Lond. 84, 4I.

Mameesh, M. S. \& Johnson, B. C. (1959). Proc. Soc. exp. Biol. Med. ror, 467.

Mitchell, H. H. (1934). F. biol. Chem. ro5, 537 .

Mitchell, H. H. \& Beadles, J. R. (I950). F. Nutr. 40, 25.

Nasset, E. S. (1956). In Some Aspects of Amino Acid Supplementation, p. 3. [W. H. Cole, editor.] New Brunswick, NJ : Rutgers University Press.

Rama Rao, P. B., Metta, V. C. \& Johnson, B. C. (1959). F. Nutr. 69, 387.

Rogers, Q. R., Chen, M. L., Peraino, C. \& Harper, A. E. (1960). F. Nutr. 72, 33 I.

Schreiber, M. \& Elvehjem, C. A. (1955). F. Nutr. 57, I33. 